\title{
Mucus-net feeding on organic particles by the vermetid gastropod Dendropoma maximum in and below the surf zone
}

\author{
Gal Ribak ${ }^{1,2,3, *}$, Joseph Heller ${ }^{2}$, Amatzia Genin ${ }^{1,2}$ \\ ${ }^{1}$ The Inter-University Institute for Marine Science, PO Box 469, 88103 Eilat, Israel \\ ${ }^{2}$ Department of Evolution, Ecology and Systematics, Institute of Life Sciences, The Hebrew University of Jerusalem, 91904 \\ Jerusalem, Israel \\ ${ }^{3}$ Present address: Department of Biology, Technion-Israel Institute of Technology, 32000 Haifa, Israel
}

\begin{abstract}
Dendropoma maximum is a sessile marine gastropod that inhabits reef flats along a distinct, shallow, sub-tidal zone and uses mucus nets for passive suspension feeding. We tested the hypothesis that surface waves improve food capture by animals inhabiting the surf zone. D. maximum feeds mainly on suspended detrital particles that are highly abundant in its habitat. Its feeding strategy depends on ambient currents, not only for the transport of suspended particles to the filtering apparatus but also for the spreading of the mucus net and for determining its shape and size. Using an in situ experiment, we observed a 1.7-fold decrease in prey capture rates among animals transplanted from the surf zone to $5 \mathrm{~m}$ depth, where most of the flow was unidirectional. Part of the reduction in feeding rate could be attributed to a lower concentration of detrital particles at the deeper habitat. However, laboratory experiments in a recirculating flume showed that the mucus net produced by the animals under oscillatory flow was larger than under unidirectional flow. D. maximum is well-adapted for trapping detrital particles under the unique hydrodynamic conditions in the surf zone.
\end{abstract}

KEY WORDS: Suspension feeding $\cdot$ Oscillatory flow $\cdot$ Sea waves $\cdot$ Detritus

- Resale or republication not permitted without written consent of the publisher

\section{INTRODUCTION}

Passive suspension feeders rely on ambient currents for the delivery of their food (Wildish \& Kristmanson 1997). Many studies of the interactions between suspension feeders and food delivery have focused on current speed, particle size and density, and their effects on the animals' functional response (Rubenstein \& Koehl 1977, LaBarbera 1978, 1984, Muschenheim 1987, Riisgard 1989, 1991, Riisgard et al. 1993, Navarro \& Widdows 1997, Riisgard \& Manriquez 1997, Fabricius et al. 1998). Some suspension feeders can control feeding rates by changing their mode of feeding from active to passive suspension feeding (Trager et al. 1990, Trager \& Genin 1993) or by switching from deposit feeding to suspension feeding (Taghon et al.
1980, Miller et al. 1992). These animals usually respond to changes in flow speed and food concentration or flux. Only a few studies examined in situ food capture under conditions of oscillatory flow, a condition typical of the shallow sub-tidal environment (Denny 1988, Lugo-Fernandes et al. 1998).

The vermetid gastropod Dendropoma maximum Sowerby, 1825 is a common inhabitant of Indo-Pacific coral reefs. It is most abundant on shallow reef flats, at sites exposed to waves (Hughes \& Lewis 1974, Smalley 1984). This sessile animal has an irregularly uncoiled shell, cemented to the substrate (Keen 1961). It feeds by excreting a mucus net that originates from a large pedal gland and spreads into the water via special, grooved tentacles. The net remains in the water for 20 to $40 \mathrm{~min}$, close to the substrate, after which it is pulled 
to the mouth and ingested together with all the trapped particles (Morton 1950, Hughes \& Lewis 1974). The animal's diet consists mostly of plankton, meiobenthos and detritus (Kappner et al. 2000). The use of mucus nets for suspension feeding is unique because unlike most passive suspension feeders that have a fixed filtering organ, the mucus net can change size and shape in response to different current conditions and its area can be larger than the animal itself. Hughes \& Lewis (1974) observed that individuals held in containers with still water usually fail to produce mucus nets and that the direction in which the net is extended corresponds to the flow direction. Hence, currents appear to affect net spreading. Hughes \& Lewis (1974) and Smalley (1984) suggested that the distribution of $D$. maximum on exposed reef flats is determined by feeding. However, very little is known about the mechanisms of mucus net formation, spreading, and food capturing.

Waves generate flow patterns with cyclic periods of acceleration and deceleration and rapid current reversals. Peak velocities can be much higher than the average current speed and the flow is generally turbulent. At depths greater than half the wave length, the currents are relatively unidirectional with a well-developed benthic boundary layer with slow flow. The turbulent benthic boundary layer of oscillatory flow varies in thickness and fluid velocity during the wave cycle, and as a result, large shear forces and accelerations are augmented on the seabed (Denny 1988, Miller et al. 1992). Apart from the different flow environment, waves may affect both the rate and type of particles encountered by the animal's trapping mechanism (Muschenheim 1987, Miller \& Sternberg 1988). The higher turbulence in the surf zone can markedly increase particle transport from the water column to the bottom but can also resuspend bedload particles (Denny \& Shibata 1989). Miller et al. (1992) reported a change in feeding behavior of several suspension feeders in response to increased oscillatory flow. However, our understanding of suspension feeding under wave conditions is rather poor.

This study examines the effects of unidirectional and oscillatory flows on in situ and in vitro suspension feeding by Dendropoma maximum.

\section{MATERIALS AND METHODS}

Study site. Field and laboratory work were conducted at the H. Steinitz Marine Biology Laboratory (MBL), on the west shore of the Gulf of Aqaba $\left(29^{\circ} 30^{\prime} 40^{\prime \prime} \mathrm{N}, 34^{\circ} 55^{\prime} 58^{\prime \prime} \mathrm{E}\right)$. Waves propagate towards these shores at a sharp angle, low amplitudes and with a frequency of approximately $0.4 \mathrm{~Hz}$, due to the year- round north wind, low fetch and seabed topography. Oceanographic and meteorological conditions in the Gulf of Aqaba have previously been described by Reiss \& Hottinger (1984), Genin et al. (1995b) and Genin \& Paldor (1999). Occasional southern winds generate stronger waves due to higher fetch, but such instances are rare. The amplitude of the sea-level tide ranges from 30 to $100 \mathrm{~cm}$, exposing the reef flat during extreme low tides, which occur a few times a year, usually during late summer (Loya 1976). The experimental work described herein focused on the shallow subtidal zone, where the actual depth of the seabed changes with tide. For simplicity, all the depths reported here are relative to the reef flat (i.e. the yearly minimum water level) and not to actual water depth.

Density distribution. The distribution of Dendropoma maximum was sampled across the reef flat by randomly placing 20 quadrates $(1 \times 1 \mathrm{~m})$ along each of five $100 \mathrm{~m}$ long transects (A to E in Fig. 1). All transects were parallel to the seaward edge of the reef flat. On the flat, the distance between transects B to D was $7 \mathrm{~m}$. Transects $A$ and $E$ were along the upper $1 \mathrm{~m}$ of the vertical wall of the flat's sea- and lee-ward ends, respectively. Due to the scarcity of $D$. maximum in other parts of the reef, its incidence in the lagoon and at depths greater than approximately $2 \mathrm{~m}$ below the reef flat $(\mathrm{G}$ and $F$, respectively) was surveyed qualitatively.

Transplantation procedure. Individuals used in the in situ experiment were collected from horizontal surfaces at a depth of 0.5 to $1 \mathrm{~m}$. The animals were detached from the bottom using a chisel and hammer,

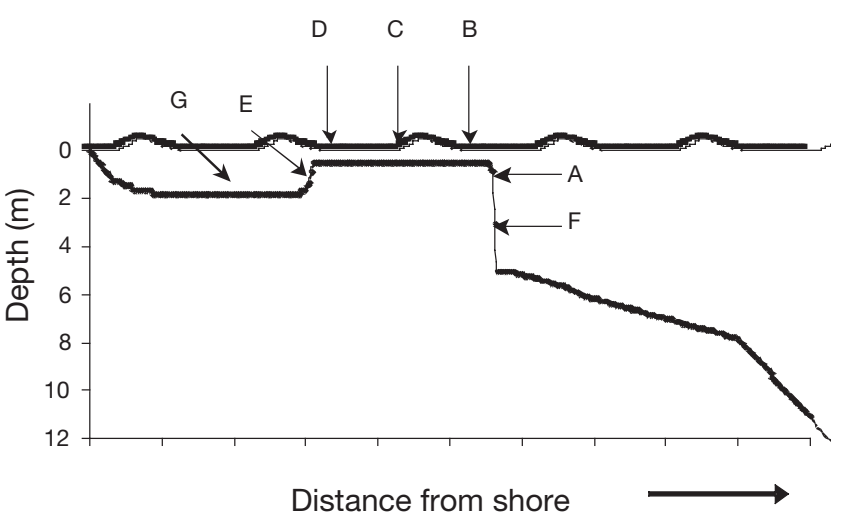

Fig. 1. Schematic drawing (not to scale) of a cross-shore transect along the reef flat. Arrows A to E indicate the location of the long-shore transects in relation to the reef flat. A: upper $1 \mathrm{~m}$ of the vertical wall facing seawards; B: the edge of the reef flat facing the coming waves; $\mathrm{C}$ : on the reef flat $7 \mathrm{~m}$ further towards the shore (approximately the center of the reef flat); D: the horizontal edge of the reef flat facing away from the coming waves; E: the vertical wall of the reef flat facing away from the waves. Two additional locations were only scanned for individuals of Dendropoma maximum. F: the deeper part (>2 $\mathrm{m}$ ) below the reef flat on the vertical wall facing the waves; $\mathrm{G}$ : the bottom of the shallow $(<1.5 \mathrm{~m})$ lagoon 
with the substrate they grew on (mainly dead corals) to avoid any damage to the shells. The animals were transported to the lab in a large seawater container and returned to sea at a depth of $1 \mathrm{~m}$ within an hour of collection. There, the animals were cemented onto large $(30 \times 70 \mathrm{~cm})$ limestone plates using underwater epoxy (A-778 Splash Zone Compound, Kop-Coat) and left to acclimatize for a period of $1 \mathrm{wk}$. Daily observations were made to verify that all the transplanted animals were producing mucus nets. Afterwards, the animals were randomly divided into 2 groups: 13 were transplanted to a shallow site, $1.5 \mathrm{~m}$ below the reef flat, and 10 to a deep site, $5 \mathrm{~m}$ below the flat, (hereafter, referred to as the 'shallow-transplanted' and the 'deep-transplanted' groups, respectively). The horizontal distance between the sites was $40 \mathrm{~m}$. In addition to the transplanted individuals, 17 intact Dendropoma maximum, original inhabitants of the shallow site, were individually tagged (hereafter, referred to as the 'non-transplanted' group). Seven individuals from the non-transplanted group neighbored the shallow-transplanted animals (at $1.5 \mathrm{~m}$ depth), while the other 10 were $4 \mathrm{~m}$ away, on the reef flat ( $0 \mathrm{~m}$ depth), where D. maximum was highly abundant. The survival and feeding behavior of the non-transplanted group (17 animals in total) was monitored as a control for the effects of the transplanting procedure.

Environmental conditions at the sites. The current velocity was recorded every $0.5 \mathrm{~s}(2 \mathrm{~Hz})$ for $40 \mathrm{~min}$ at each of the shallow and deep sites using an electromagnetic current meter (Model S4, InterOcean) mounted $50 \mathrm{~cm}$ above the seabed. Since only 1 current meter was available, the currents were first recorded at the deep site and then at the shallow site. At the same time, 2 submerged pumps (one at each site), located $60 \mathrm{~cm}$ above the seabed, delivered water to the beach ( 200 $\left.\mathrm{l} \mathrm{min}^{-1}\right)$ through $5 \mathrm{~cm}$ diameter PVC pipes. Plankton samples were obtained by filtering the pumped water through a $100 \mu \mathrm{m}$ plankton net for $45 \mathrm{~min}$. The exact pumping rate was measured before each sample collection, to allow calculations of plankton concentrations. The collected plankton was fixed in $4 \%$ formalin in seawater and sub-samples, taken with a $2.5 \mathrm{ml}$ Stemple Pipette (Omori \& Ikeda 1984), were counted under a dissecting microscope. The number of sub-samples counted was such that at least 400 organisms were counted from each sample to assure reliable representation of all abundant planktonic species. Copepod carcasses (Genin et al. 1995a) were counted separately from live copepods. Detritus particles, including fragments of macroalgae, animal parts and unidentified organic particles were pooled into a single category, hereafter referred to as 'fragments'. Chlorophyll a (chl a) concentrations were measured at each site by taking a water sample $(280 \mathrm{ml}) 40 \mathrm{~cm}$ above the seabed, filtering the water on a GF/F filter (Whatman) and extracting the chl a for $24 \mathrm{~h}$ in $90 \%$ acetone at $4^{\circ} \mathrm{C}$ as in Strickland \& Parsons (1972). The extracted chl a concentration was measured using a TD 700 fluorometer (Turner device).

The entire sampling procedure was repeated each sampling day $(\mathrm{n}=41 \mathrm{~d})$. A sampling day started with a dive to the deep site where a $280 \mathrm{ml}$ water sample was collected for chl a analysis, and the current meter deployed. Two divers measured the area of mucus nets, and proceeded to collect them as described below. This work lasted approximately $40 \mathrm{~min}$, after which the divers repeated the procedure at the shallow site. The plankton pumps were set to work simultaneously with the dive to each site. The average current speed, zooplankton density and chl a concentration for each site in each sampling day were used for inter-site comparison of currents and food.

Analysis of mucus nets. We sampled newly-secreted nets precisely $20 \mathrm{~min}$ after the initiation of their excretion. First, the existing (old) mucus net was removed. This stimulated Dendropoma maximum to start producing a new net within less than a minute. Next, a $0.5 \mathrm{~mm}$ metal wire was laid on the outside perimeter of the animal's shell aperture, forming a ring $(3 \mathrm{~cm}$ diameter) through which the mucus net was excreted unobstructed. Twenty min later, the mucus was collected by raising the ring and turning it 3 to 5 times to roll and bundle the mucus net around it. Prior to net collection, the area of the mucus net was estimated by placing a $20 \times 20 \mathrm{~cm}$ metal grid a few centimeters above the net and counting the number of $1 \mathrm{~cm}^{2}$ squares that overlapped with the net. When sampled at night, mucus net area was not measured, and the collection of mucus nets was performed using a dimmed flashlight covered with a red filter. Collecting the mucus after 20 min ensured that the mucus net would be sampled prior to the start of its retrieval by the animal. Preliminary observations (G. Ribak et al. unpubl. data, $\mathrm{n}=102$ ) showed that, during the day, D. maximum retrieves its net $>20$ min after initiating its spreading in $>90 \%$ of the cases, (see also Kappner et al. 2000).

The collected nets were transferred to the laboratory and kept frozen $\left(-70^{\circ} \mathrm{C}\right)$ for later analysis. Food particles were dislodged from the net by disintegrating the mucus in $0.35 \%$ sodiumhypochlorite solution $(\mathrm{NaOCl})$ in water (A. Hudson pers. comm.) and filtering the solution through a $100 \mu \mathrm{m}$ plankton net. We tested the adequacy of the technique, and the ideal concentration of the $\mathrm{NaOCl}$ solution by running preliminary trials using a known number (5 to 6) of copepods at a gradient of concentrations of the solution (prepared from a stock solution of $10 \%$ active chlorine, $\mathrm{NaOCl}$, Frutarom). All copepods were retrieved up to a concentration of $0.5 \%$. At concentrations $>0.5 \%$, the external 
integument of the copepods showed signs of digestion. At concentrations $<0.35 \%$, the separation of the particles from the mucus was incomplete. No visible change in the size of fragments was detected as the

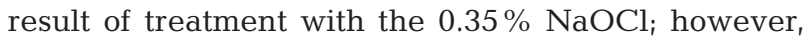
some pigmented fragments showed a tendency to bleach. Food particles were thereby counted separately for organisms (plankton and meiofauna) and fragments. Zooplankton was counted under a dissecting microscope as described above. To estimate the biomass of fragments, we recorded their size using a CCD video camera, mounted on a dissecting microscope and connected to a SONY EVO-9800P VCR. The area of each fragment was measured using a Scion LG-3 frame-grabber and image-analysissoftware (ScionImage, Scion)

Flow tank experiments. The effect of flow regime (unidirectional and waves) and phytoplankton concentration on the feeding rate of Dendropoma maximum was examined in the recirculating flume described by Trager \& Genin (1993). Flow was generated by a propeller and a small electric motor connected to a desk computer, allowing full control of flow speed and direction. Waves were generated by changing the direction of the flow at a frequency of $0.4 \mathrm{~Hz}$ (similar to the average observed in situ). The waves generated were asymmetrical, with a weak residual forward flow (Fig. 2). The flow in the flume, at the height of the animal's aperture (3 $\mathrm{cm}$ above bottom) was measured,

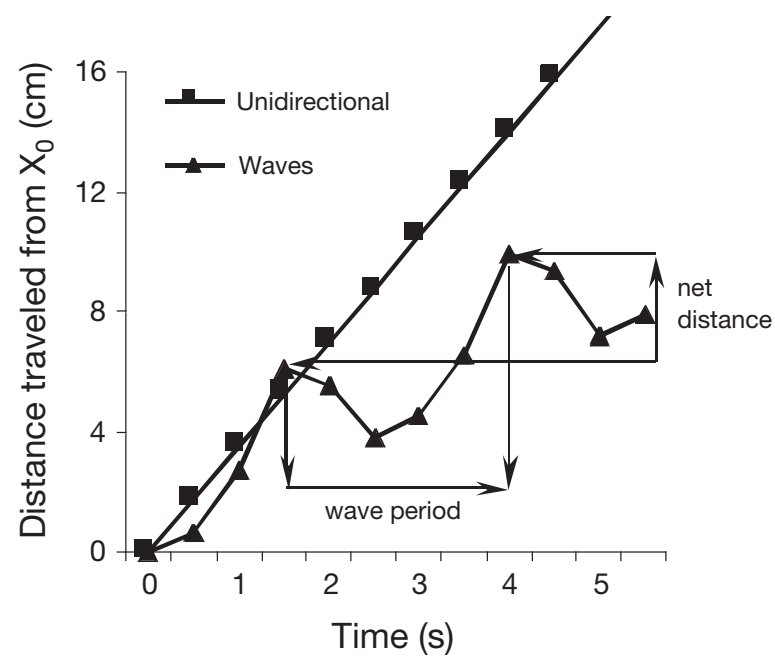

Fig. 2. Movement of suspended particles at the 2 flow regimes generated within the flume. The vertical axis is the propagation of the particle downstream from the initial position of the particle at the start of the measurement $\left(\mathrm{X}_{0}\right.$, set at convenience as 0 ). In unidirectional flow (ם), the particles move at a steady speed of $3.5 \mathrm{~cm} \mathrm{~s}^{-1}$, while in oscillatory flow $(\mathbf{\Delta})$, the particles move back and forth; however, the average flow of water the animal was exposed to (regardless of direction) was $3.5 \mathrm{~cm} \mathrm{~s}^{-1}$. The net distance a particle moved per wave cycle (depicted by the arrows) was $3.8 \mathrm{~cm}\left(1.5 \mathrm{~cm} \mathrm{~s}^{-1}\right)$. Each cycle lasted $2.5 \mathrm{~s}(0.4 \mathrm{~Hz})$. See text for details without the animals being present, using video tracking of suspended particles. The flow was adjusted so that the RMS (Root Mean Square) speed under the oscillatory flow would equal that of the unidirectional flow. Two RMS speeds were used: 3.5 and $5.5 \mathrm{~cm} \mathrm{~s}^{-1}$, with the average particle displacement in the corresponding oscillatory motions equal to 1.5 and $1.3 \mathrm{~cm}$ $\mathrm{s}^{-1}$, respectively. Each experimental trial used a single D. maximum, cemented to a thin smooth plate $(20 \times$ $30 \mathrm{~cm})$, positioned at the center of the flume's working section $(20 \times 30 \times 80 \mathrm{~cm})$ with the animal's aperture oriented upcurrent. The experimental animals were kept at sea between trials and were brought to the flume after their mucus net was removed. Trials began as soon as the animal started to secrete the new mucus net in the flume (typically $<1$ min after transfer), and lasted precisely $20 \mathrm{~min}$. At the end of the trial, the mucus net was collected using a pre-weighted wire ring, as described above. Each animal ( $n=5)$ was tested 5 times at each combination of current regime (unidirectional, oscillatory) and speed $\left(3.5,5.5 \mathrm{~cm} \mathrm{~s}^{-1}\right)$. The choice of flow speeds used in the flume experiment was not random. The lower flow speed $(3.5 \mathrm{~cm}$ $\mathrm{s}^{-1}$ ) we used was typical for the deep site (an average current speed of $3.2 \mathrm{~cm} \mathrm{~s}^{-1}$ was measured at our study site $8 \mathrm{~cm}$ above the sea bed, Genin et al. 2002). The faster flow speed $\left(5.5 \mathrm{~cm} \mathrm{~s}^{-1}\right)$ was taken as an upper value that deep suspension feeders may rarely encounter at strong currents.

Prior to each trial, the water in the flow tank was filtered through a $100 \mu \mathrm{m}$ plankton mesh to remove larger particles and fragments (but retaining phytoplankton). A water sample $(280 \mathrm{ml})$ was then taken to determine the concentration of chl $a$ in the flume. The water sample was filtered on a GF/F (Whatman) filter and the filter incubated in $10 \mathrm{ml}$ of $90 \%$ acetone for $\mathrm{chl}$ a extraction as mentioned above. After each trial, the chl a content of the mucus net was similarly determined by incubating the ring with the attached mucus in $20 \mathrm{ml}$ of $90 \%$ acetone for $24 \mathrm{~h}$ to extract the chl a. The mucus itself has no auto-fluorescence that could bias chl a measurement (Kappner et al. 2000). After extraction, the ring with the remaining attached mucus was dried at $60^{\circ} \mathrm{C}$ for $24 \mathrm{~h}$, and weighed. Weight loss due to acetone extraction and ring handling was evaluated by weighing dried nets, extracting the chl $a$ in acetone and then drying and re-weighing. The average loss was $31.3 \%(\mathrm{SD}=11.4, \mathrm{n}=17)$. To compare chl a capture at the different flow regimes, the volume of water cleared of chl a per unit of time (clearance) was calculated as: clearance $=(\mathrm{g}$ chl a accumulated on the net in $20 \mathrm{~min}) /\left(\mathrm{g} \mathrm{chl} \mathrm{a} \mathrm{l}^{-1}\right.$ in the flume).

Clearance per weight of net was calculated by dividing the clearance by the weight of the dried net after chlorophyll extraction. 
Estimating total carbon per net. To estimate the relative contribution of phytoplankton, zooplankton and fragments, we converted all values to organic carbon based on a chl a:C ratio of 1:60 reported from our study site by Yahel et al. (1998). The contribution of phytoplankton could not be calculated in situ, as both phytoplankton and some fragments included chl a. The carbon gain through phytoplankton feeding was, therefore, estimated by combining the observed clearance rate at $5.5 \mathrm{~cm} \mathrm{~s}^{-1}$ in the flume experiment with the ambient in situ concentration of phytoplankton in fragment-free samples at the sites.

Biomass from the zooplankton counts was achieved by sorting animals into 3 size categories according to body length $(<300 \mu \mathrm{m} ; 300<$ length $<700 \mu \mathrm{m}$; $>700 \mu \mathrm{m})$. The middle value of each size class $(200,500$ and $800 \mu \mathrm{m}$, respectively) was then converted to organic carbon weight according to Rodriguez \& Mullin (1986) and multiplied by the number of organisms within the category. This conversion is likely to overestimate the organic carbon weight as the equation is based on zooplankton samples that included mainly crustaceans, while our zooplankton included mainly foramenifera and ostracods that have lower carbon content per body size than copepods.

The carbon contribution via fragments was estimated based on our direct size measurements of the fragment trapped on the mucus nets in situ. The total area of fragments $\left(\mathrm{mm}^{2}\right)$ from each net was converted to ash free dry weight (AFDW, mg) based on the following calibration curve:

$$
\log (\mathrm{AFDW})=0.6129 \log (\text { area })-0.9682
$$

This relationship $\left(\mathrm{r}^{2}=0.9722, \mathrm{n}=7\right.$ ) was obtained by measuring the areas and AFDW of the fragments in 7 different aliquots drawn from a single pump sample. AFDW was obtained after filtering the measured fragments samples through pre-weighed, pre-combusted GF/A filters (Whatman) and combusting the filters in $450^{\circ} \mathrm{C}$ for $4 \mathrm{~h}$, as described by Omori \& Ikeda (1984). Carbon was assumed to contribute $40 \%$ of the AFDW of organic matter as reported (for plankton) by these authors.

Sample size. Currents and plankton concentrations were measured at the shallow and deep sites in October 1998 (17 days and 4 nights) and in April to May 1999 (16 days and 4 nights). Mucus nets were measured for area and collected, at each site, simultaneously with current measurements and plankton collection, as described above. Since the net area was not measured during the night, we obtained a total of 41 samples of environmental conditions and mucus nets, only 33 of which had measurements of the net area. Due to the tedious quantification of fragment size, the food content of the mucus nets was only analyzed from the nets of 12 randomly-selected sampling dates (8 days, 4 nights) in October 1998 and 13 sampling dates (9 days, 4 nights) in April to May 1999. Within each sampling day, we only analyzed the nets of 6 animals from the deep-transplanted group and 6 from the shallow-transplanted group. In total, we analyzed the content of 300 mucus nets from 25 sampling days. The nets from all other Dendropoma maximum in the shallow-transplanted, deep-transplanted and non-transplanted groups were measured for area and collected each sampling day without further processing in order to treat all the transplanted and non-transplanted animals equally.

Statistical analysis. All statistical tests were preformed using STATISTICA (StatSoft). Due to logistical limitations, our samples were replicated in time, rather than sites. Our statistical analysis is, therefore, based on repetitive (daily) monitoring of the flow and plankton conditions at the same deep and shallow sites. Similarly, mucus nets were sampled on different days from the same individuals at the 2 sites. We, therefore, used repetitive measures design (StatSoft 1995). Inter-site differences in specific environmental conditions (currents, chl a) were tested using a paired $t$-test. The inter-site difference in plankton concentration was tested using Repeated Measures ANOVA (RMANOVA). The average mucus net area of the 4 treatment groups described above was compared by a 1-way ANOVA for repeated measures. The average biomass of the fragments (total AFDW net ${ }^{-1}$ ) on the deep and shallow mucus nets was compared using paired $t$-test, where the different sampling days served as repetitions in all cases. ANOVA assumptions (homogeneity of variance and the normal distribution of residuals) were tested and data transformation was performed when necessary (Underwood 1981)

\section{RESULTS}

\section{Density distribution}

The density of Dendropoma maximum along the reefflat increased towards the seaward edge (Fig. 3). High density was found on the upper $1 \mathrm{~m}$ of the seaward vertical wall. D. maximum was absent deeper than $3 \mathrm{~m}$ below the reef flat and was rare in the shallow lagoon. The few individuals found in the lagoon were living on rocks likely dislodged from the near by reef flat.

\section{Environmental conditions at the sites}

Daily variations in the concentrations of phytoplankton and most zooplankton groups at the deep 


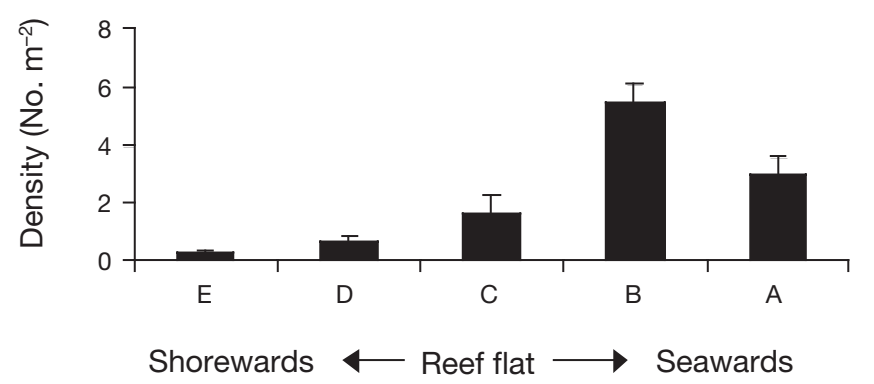

Fig. 3. Dendropoma maximum. Average population density measured along the reef flat at 5 parallel transects. The letters indicating transects are as in Fig. 1. Error bars are SE. $\mathrm{n}=20$ for each transect

and shallow sites were highly correlated (Table 1). The currents, however, were very different at the 2 sites, with oscillatory currents dominating the shallow site (Fig. 4), producing significantly faster currents ( $\mathrm{p}<0.01$; paired $t$-test) than the typical unidirectional flow at the deep site. No significant correlation was found in the current speed at the 2 sites $(r=0.29, p>$

Table 1. Environmental conditions at the deep and shallow sites. Averages $( \pm \mathrm{SD})$ of $41 \mathrm{~d}$ are listed. $\mathrm{p}$ is the significance level (paired $t$-test for currents and phytoplankton; ANOVA for plankton abundance) of inter-site differences marked as follows: ${ }^{*} \mathrm{p}<0.05 ;{ }^{* *} \mathrm{p}<0.01{ }_{i}{ }^{* * *} \mathrm{p}<0.001$; ns: no significance. $\mathrm{r}$ is the Pearson coefficient for the correlation between the 2 sites. The significance of $r$ is indicated as for $p$

\begin{tabular}{|c|c|c|c|c|}
\hline Environmental condition & Deep & Shallow & $\mathrm{p}$ & $\mathrm{r}$ \\
\hline Current speed $\left(\mathrm{cm} \mathrm{s}^{-1}\right)$ & $\begin{array}{c}6.04 \\
(3.27)\end{array}$ & $\begin{array}{c}7.5 \\
(2.58)\end{array}$ & ${ }^{* *}$ & $0.29^{\text {ns }}$ \\
\hline $\begin{array}{l}\text { Phytoplankton concentration } \\
\left(\mu \mathrm{C} \mathrm{C}^{-1}\right)\end{array}$ & $\begin{array}{c}16.3 \\
(3.78)\end{array}$ & $\begin{array}{c}14.9 \\
(3.31)\end{array}$ & $* * *$ & $0.846^{* * *}$ \\
\hline \multicolumn{5}{|l|}{ Plankton abundance (no. $\mathrm{m}^{-3}$ ) } \\
\hline Copepoda & $\begin{array}{c}949.5 \\
(677.0)\end{array}$ & $\begin{array}{c}1219.3 \\
(1290.2)\end{array}$ & ns & $0.625^{* * *}$ \\
\hline Nauplii & $\begin{array}{c}603.8 \\
(684.3)\end{array}$ & $\begin{array}{c}634 \\
(647.4)\end{array}$ & ns & $0.765^{* * *}$ \\
\hline Mollusca & $\begin{array}{c}158.4 \\
(146.8)\end{array}$ & $\begin{array}{l}149.4 \\
(149.8)\end{array}$ & ns & $0.457^{* *}$ \\
\hline Polycheta & $\begin{array}{c}7.3 \\
(7.3)\end{array}$ & $\begin{array}{l}6.37 \\
(7.98)\end{array}$ & ns & $-0.04^{\mathrm{ns}}$ \\
\hline Ostracoda & $\begin{array}{c}21.6 \\
(14.2)\end{array}$ & $\begin{array}{c}32.7 \\
(18.2)\end{array}$ & $* * *$ & $0.379^{*}$ \\
\hline Algae & $\begin{array}{c}661.2 \\
(492.9)\end{array}$ & $\begin{array}{c}750 \\
(570.4)\end{array}$ & ns & $0.752^{* * *}$ \\
\hline Eggs & $\begin{array}{c}41.3 \\
(41.0)\end{array}$ & $\begin{array}{c}64.9 \\
(72.6)\end{array}$ & * & $0.516^{* * *}$ \\
\hline Foraminifera & $\begin{array}{c}80.0 \\
(34.82)\end{array}$ & $\begin{array}{c}88.43 \\
(42.49)\end{array}$ & ns & $0.4265^{* *}$ \\
\hline Fragments & $\begin{array}{c}1011.6 \\
(457)\end{array}$ & $\begin{array}{c}2402.5 \\
(1241.6)\end{array}$ & ${ }^{* * *}$ & $0.647^{* * *}$ \\
\hline Carcasses & $\begin{array}{c}76.1 \\
(47.4)\end{array}$ & $\begin{array}{c}132 \\
(91.11)\end{array}$ & $* * *$ & $0.812^{* * *}$ \\
\hline
\end{tabular}

\section{Analysis of mucus nets}

The size of mucus-net area in Dendropoma maximum in its natural habitat (non-transplanted group) on the reef flat ranged from 7 to $20 \mathrm{~cm}^{2}$, with an average of $12.8 \mathrm{~cm}^{2}(\mathrm{SD}=2.5)$ This area was significantly larger than that of the deep-transplanted and shallowtransplanted groups, and the non-transplanted individuals below the flat $(\mathrm{p}<0.001,1$-way RMANOVA, Table 2). Net size did not differ between shallow-transplanted and deep-transplanted animals ( $p>0.28$, Tukey post hoc test), nor were the net sizes of the 2 groups correlated in different days $(\mathrm{r}=$ $0.13, \mathrm{p}>0.4, \mathrm{n}=33$ ). At the shallow site (below the reef flat), the net size of transplanted and non-transplanted groups did not differ significantly $(\mathrm{p}>$ 0.16 , Tukey post hoc), exhibiting a significant correlation in time $(\mathrm{r}=0.39, \mathrm{p}<$ $0.03, \mathrm{n}=33$ ). The area of the net was significantly correlated with current speed at the deep site $(r=0.5, p<0.01$, $\mathrm{n}=33$ ), but not at the shallow site ( $\mathrm{r}=$ $-0.1, \mathrm{p}>0.42, \mathrm{n}=33$ ).

The mucus net of Dendropoma maximum contained a few planktonic organisms (Fig. 5), with no apparent difference in the taxonomic composition at the 2 depths ( $p>0.292$, RMANOVA) and no significant difference between day and night ( $p$ > 0.147, RMANOVA). In terms of carbon, the average catch per net was $11.4(\mathrm{SD}=12.2)$ and $11.5(\mathrm{SD}=16.9)$ $\mu \mathrm{g}$ C net ${ }^{-1}$, for the shallow and deep animals, respectively. Most of the diet, however, consisted of fragments. The average AFDW of the fragments trapped on the nets at the shallow site was 1.7 times higher than that at the deep site $0.369(\mathrm{SD}=0.296)$ versus $0.213(\mathrm{SD}=0.125) \mathrm{mg}$ AFDW net $^{-1}$, respectively $(\mathrm{p}<0.03$, paired $t$-test; Fig. 6). 

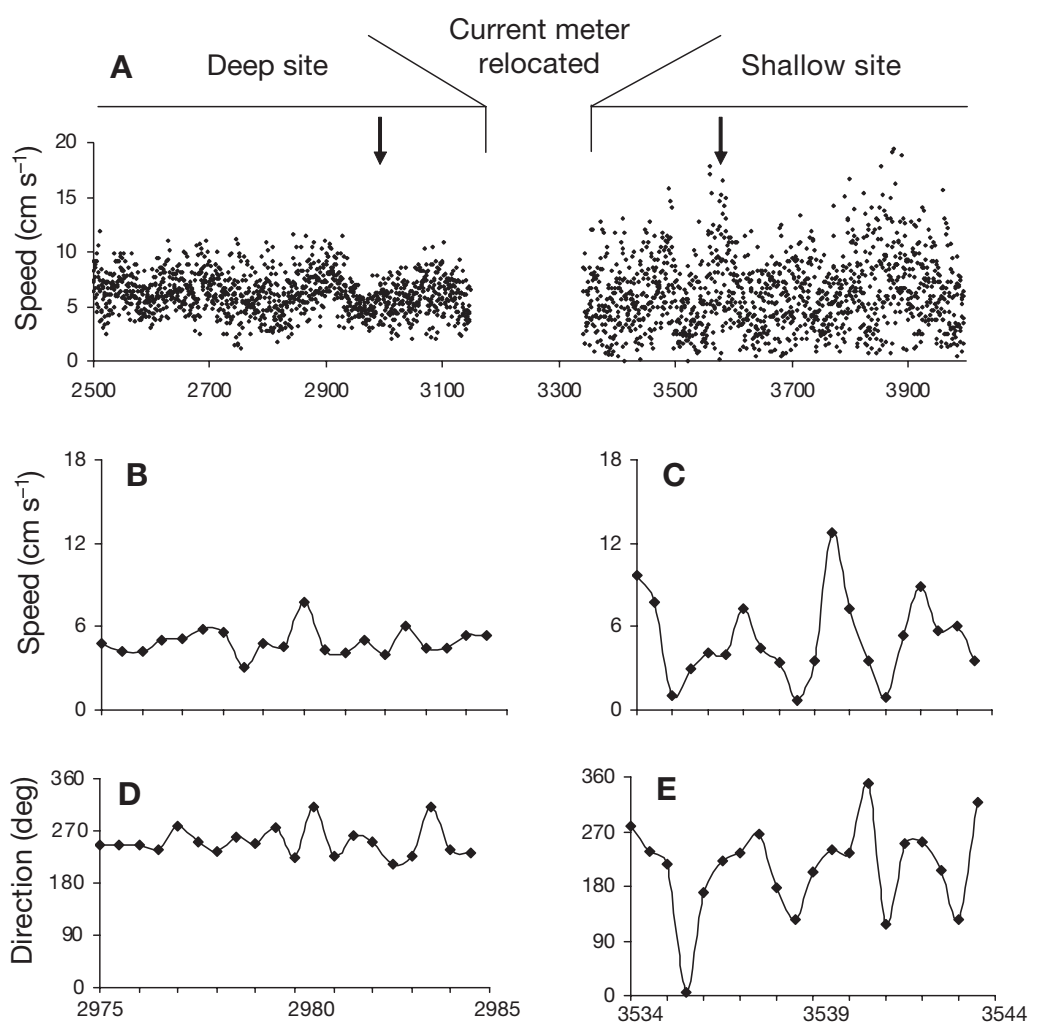

Time (s)

Fig. 4. Current meter data from 1 sampling day (28 September 1998). (A) Current speed at $0.5 \mathrm{~m}$ above the seabed recorded every $0.5 \mathrm{~s}$. Measurements started at the deep site (2500 to $3200 \mathrm{~s}$ ) and then the current meter was moved ( 3200 to $3400 \mathrm{~s}$ ) to the shallow site ( 3400 to $3900 \mathrm{~s}$ ). The 2 arrows indicate intervals of $10 \mathrm{~s}$ each, which are plotted using finer scale in panels B and C (speed), and $\mathrm{D}$ and $\mathrm{E}$ (direction) at the deep $(\mathrm{B}, \mathrm{D})$ and shallow $(\mathrm{C}, \mathrm{E})$ sites. Note the difference in flow characteristics between the unidirectional current at the deep site and the oscillatory current at the shallow site despite the similarity in average current speed $\left(\sim 6 \mathrm{~cm} \mathrm{~s}^{-1}\right)$

\section{Flow tank experiments}

A significant increase in clearance rate by a factor of 2.42 (SD = 0.33) ( $\mathrm{p}<0.006$, RMANOVA) occurred when the unidirectional current of $3.5 \mathrm{~cm} \mathrm{~s}^{-1}$ was changed to oscillatory flow with similar RMS speed. The enhanced clearance rate was probably due to a 3 -fold $(\mathrm{SD}=1.4)$ increase in the weight of the mucus net $(\mathrm{p}<$ 0.013, RMANOVA), as clearance rates per net weight did not differ among the 2 flow regimes (Fig. 7). No such difference in clearance rate was found when the flow speed was $5.5 \mathrm{~cm} \mathrm{~s}^{-1}$ (Table 3). An increase in flow speed from 3.5 to $5.5 \mathrm{~cm} \mathrm{~s}^{-1}$ caused an increase in both net weight and clearance rate ( $p<0.012$, RMANOVA).

The rate of phytoplankton clearance was correlated with net weight $(\mathrm{r}=0.783, \mathrm{p}<0.001, \mathrm{n}=100)$. Surprisingly, no significant correlation was found between the amount of chl a caught per $g$ net and the chl a flux (speed $\times$ concentration) $(\mathrm{r}=0.097, \mathrm{p}>0.335, \mathrm{n}=100)$.
Total carbon per net

In terms of carbon, the feeding rate per animal per single net cycle was as follows: phytoplankton 17.3 and 15.8 $\mu \mathrm{g} \mathrm{C}$ net $^{-1}$ cycle $^{-1}$ for the deep- and shallow-transplanted animals, respectively. The carbon content of the in situ trapped fragments ( $40 \%$ of AFDW) was 85 and $148 \mu \mathrm{g} \mathrm{C}$ net $^{-1}$, while that of zooplankton was 11.5 and $11.4 \mu \mathrm{g} \mathrm{C}$ net $^{-1}$, at the deep and shallow sites, respectively. Thus, on average at the shallow site, fragments constituted $84.5 \%$ of the carbon ingested by Dendropoma maximum, phytoplankton $9.0 \%$ and zooplankton $6.5 \%$, while at the deep site, the proportions were $74.7,15.2$ and $10.1 \%$, respectively. The total carbon gained by a D. maximum in a single round of mucus net was $0.114 \mathrm{mg} \mathrm{C}$ net $^{-1} 20 \mathrm{~min}^{-1}$ in the deep site and $0.175 \mathrm{mg} \mathrm{C}$ net $^{-1} 20 \mathrm{~min}^{-1}$ in the shallow site.

\section{DISCUSSION}

Dendropoma maximum living at shallow depths $(1.5 \mathrm{~m}$ below the reef flat) obtained more food per mucus net than individuals living at greater depths. Our in situ and flume experiments indicated that this inter-depth difference was mostly due to the higher food flux at the shallower site and depth-related changes in the flow regime. This may suggest that the density distribution of $D$. maximum (present study, Hughes \& Lewis 1974) is related to feed-

Table 2. Dendropoma maximum. The average area $( \pm \mathrm{SD})$ of the mucus nets in the different groups, over 33 sampling days. Superscripted letters $(a, b)$ indicate statistical similarity between groups ( $p<0.05$, Tukey post hoc test). TD: Deeptransplanted group; TS: shallow-transplanted group

\begin{tabular}{|lccc|}
\hline Group & $\begin{array}{c}\text { No. of } \\
\text { animals }\end{array}$ & $\begin{array}{c}\text { Area }\left(\mathrm{cm}^{2}\right) \\
\pm(\mathrm{SD})\end{array}$ & Range $\left(\mathrm{cm}^{2}\right)$ \\
\hline $\mathrm{TD}^{\mathrm{a}}$ & 6 & $\begin{array}{c}9.2 \\
(3.26)\end{array}$ & $5.5-14.47$ \\
$\mathrm{TS}^{\mathrm{a}}$ & 8 & $\begin{array}{c}9.51 \\
(2.23)\end{array}$ & $5.88-16$ \\
Non-transplanted & 6 & $\begin{array}{c}10.62 \\
(2.71)\end{array}$ & $5.57-16.67$ \\
$\begin{array}{l}1.5 \mathrm{~m})^{\mathrm{a}} \\
\text { Non-transplanted } \\
\text { (reef-flat) }^{\mathrm{b}}\end{array}$ & 10 & $\begin{array}{c}12.77 \\
(2.48)\end{array}$ & $6.67-19.93$ \\
\hline
\end{tabular}




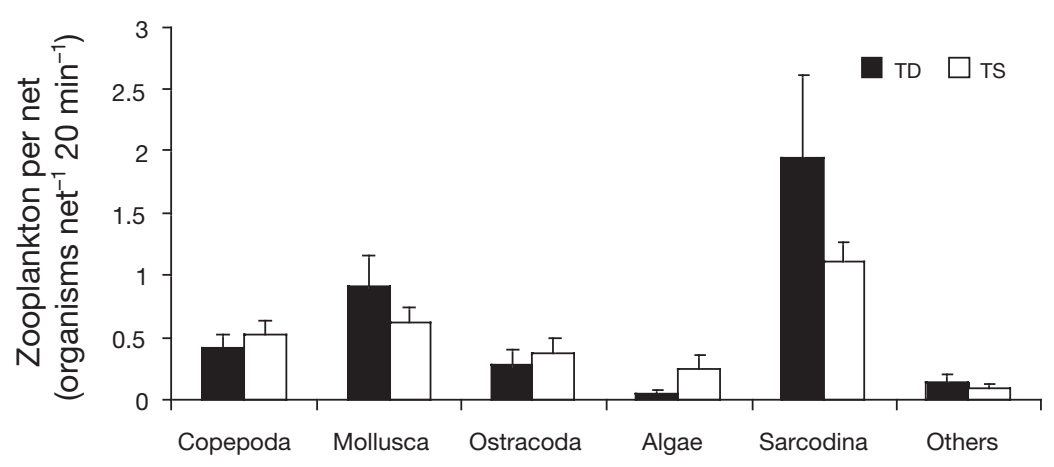

Fig. 5. The abundance of different zooplankton trapped on the mucus nets. Bars represent the average counts from nets $(n=6$ ind.) from each of the deeptransplanted group (TD) and the shallow-transplanted group (TS). Each individual was sampled for mucus once a day over a period of $25 \mathrm{~d}$. Error bars are SE

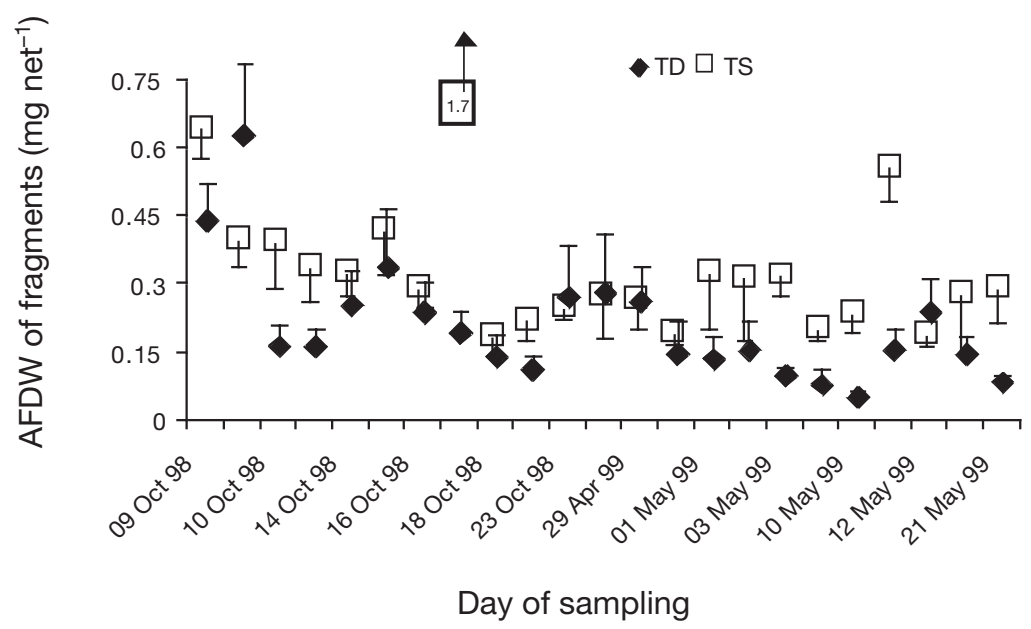

Fig. 6. Dendropma maximum. Ash free dry weight of fragments caught on the mucus nets. Fragments from mucus nets of animals transplanted to a shallow site (TS) had a higher $(p<0.03)$ organic weight than fragments analyzed from mucus nets of $D$. maximum transplanted to a deep site (TD). Each data point is the average of $6 D$. maximum for each site on 1 sampling day. On 18 October 1998, the fragments biomass reached $1.7 \mathrm{mg}$ and is therefore out of scale. Error bars are SE

ing. The maximum density was observed on the reef table facing the waves and individuals were rarely found below $3 \mathrm{~m}$ or in the lagoon. Our measurements show that, at the shallow site, D. maximum encountered faster currents, higher fragment concentrations and had larger mucus nets. That individuals transplanted to a $5 \mathrm{~m}$ depth had a higher mortality rate than those transplanted to a shallow site (37 versus $7 \%$, respectively; G. Ribek unpubl. data), suggests that the absence of $D$. maximum at deeper depths could be related to lower feeding rates. However, the precise cause for mortality and the lack of $D$. maximum at deeper depths awaits further investigation.

Dendropoma maximum is well-adapted to feeding in the physical environment of the surf-zone. Both the field measurements and the flume experiment indi- cated that net size was larger when flow was stronger or when a weak unidirectional current became oscillatory. The flume experiment, where changes in the weight of the excreted net were induced by changes in the flow regime, indicated that net size might be actively determined by the animal. An alternative, however not mutually exclusive, feeding strategy may be an enlargement of the net area due to the enhanced drag provided by waves and stronger currents, causing further spread of the net area. Regardless of the reason, the outcome was an increased net and greater particle entrapment by the animal.

Although located below the zone of maximum population density, our shallow site was within the natural depth range of Dendropoma maximum as indicated by the presence of non-transplanted animals. Our shallow site was a logistical compromise since we could not secure the large plates on which $D$. maximum was transplanted to the reef flat in a manner that would prevent their dislodgment during the occasional winter storms. We chose to cement the animals to plates, rather than directly to the natural bottom, to eliminate the variance of substrate structure. Above our shallow site, at the point of maximum population density (the reef flat), animals may experience even greater feeding rates due to exposure to stronger currents and waves. Indeed, the area of mucus nets measured from non-transplanted individuals, naturally found on the reef flat, was the highest of all groups.

A mere difference of $3.5 \mathrm{~m}$ in depth caused a great difference in environmental conditions. Waves dominated Dendropoma maximum's natural habitat, while unidirectional flow (tidal currents) dominated the deeper zone. While the concentration of living plankton was similar at the shallow and deep sites, detrital particles (fragments and carcasses) were more abundant ( 2-fold) at the shallow site. Previous studies of D. maximum diet also observed detritus on mucus nets (Kappner et al. 2000), but did not provide a quantitative estimate for the contribution of those particles to the animal's diet. Our measurement of the carbon content in the trapped fragments indicates that this type of food contributes most of the carbon ingested by 

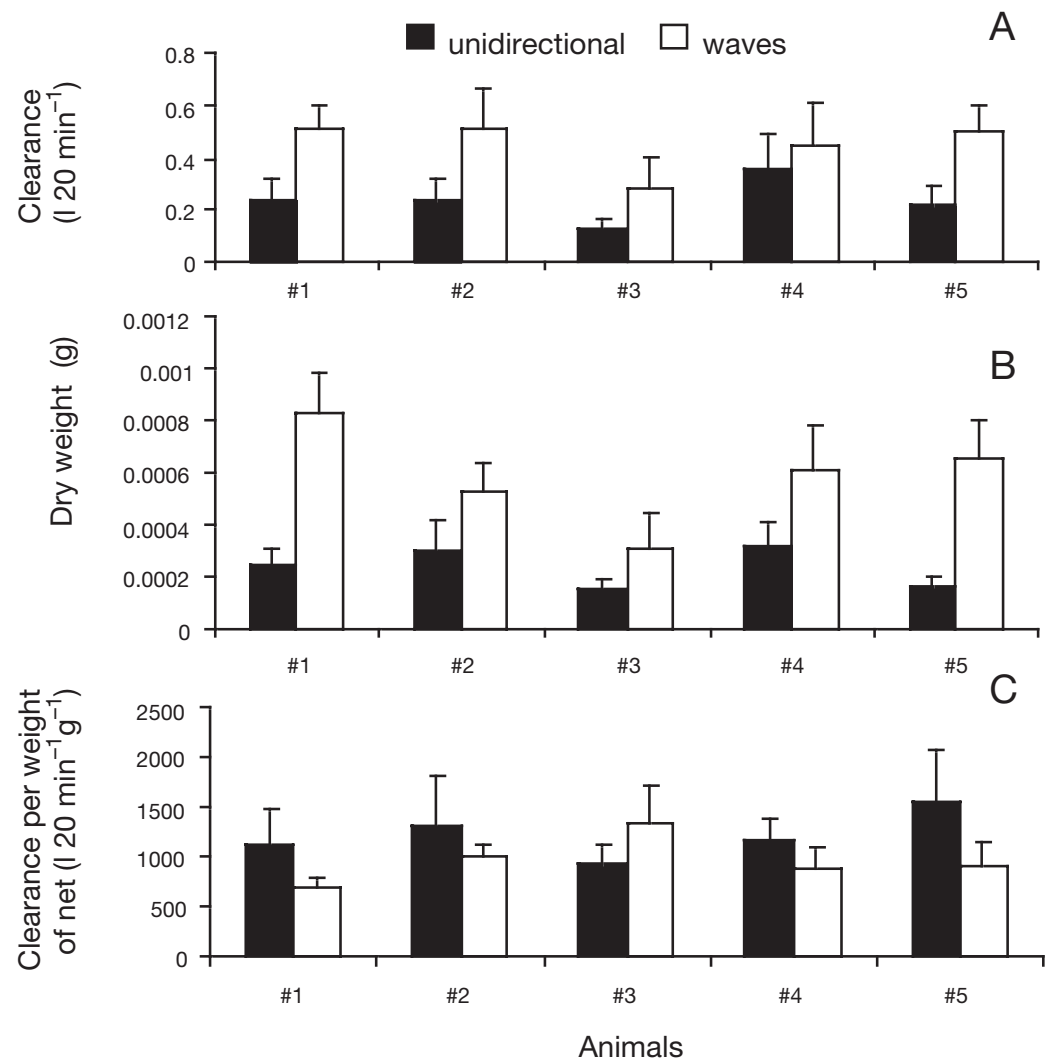

Fig. 7. Dendropoma maximum. Phytoplankton clearance, mucus-net weight, and clearance per $g$ net as measured in the flume with a flow speed of $3.5 \mathrm{~cm} \mathrm{~s}^{-1}$. Solid and open bars indicate measurements taken in unidirectional and oscillatory currents, respectively. (A) clearance rate; (B) dry weight of the mucus net; (C) clearance rate normalized to net weight

Table 3. Dendropoma maximum. The average of net weight, clearance rate and clearance per weight of net $( \pm \mathrm{SD})$ at waves versus unidirectional flow, calculated from 5 runs of the flume experiment, each with 5 individuals. The measurements were made for $20 \mathrm{~min}$ of net exposure to the flow (see text)

\begin{tabular}{|lcccc|}
\hline $\begin{array}{l}\text { Speed } \\
\left(\mathrm{cm} \mathrm{s}^{-1}\right)\end{array}$ & Flow regime & $\begin{array}{c}\text { Weight of } \\
\text { net }(\mathrm{g}) \\
\times 10^{-4}\end{array}$ & $\begin{array}{c}\text { Clearance } \\
\left(120 \mathrm{~min}^{-1}\right) \\
\times 10^{-4}\end{array}$ & $\begin{array}{c}\text { Clearance per } \\
\text { weight of net } \\
\left(\mathrm{(} \mathrm{g}^{-1} 20 \mathrm{~min}^{-1}\right)\end{array}$ \\
\hline 3.5 & Waves & 6.8 & 4710 & 787.1 \\
& Unidirectional & $(3.6)$ & $(2600)$ & $(396.0)$ \\
& & $(1.5$ & 1960 & 1016.1 \\
5.5 & Waves & 17.7 & $(1250)$ & $(869.9)$ \\
& Unidirectional & $(15.5)$ & 9660 & 860.5 \\
& 17.8 & $(5160)$ & $(682.4)$ \\
& & $(11.1)$ & $(6210)$ & 914.3 \\
& & & & $(1175.8)$ \\
\hline
\end{tabular}

D. maximum. The higher abundance of fragments at the shallow site was due either to local generation or accumulation. The action of the waves on the seabed may erode the turf on the shallow reef, releasing suspended fragments. Additionally, waves greatly enhance resuspension of bedload particles by augmenting acceleration, shear and turbulence (Denny \&
Shibata 1989). Since detrital fragments are negatively buoyant (G. Ribak pers. obs.), enhanced resuspension by waves should increase their availability for being trapped by the encrusting net of D. maximum. An elevated availability of such fragments $60 \mathrm{~cm}$ above the bottom was observed at the shallow site using our pumps.

Phytoplankton only contributes a little amount of carbon (9 to $15 \%$ ) to the diet of Dendropoma maximum. The ca. $10 \%$ higher concentration of phytoplankton at the deeper site, therefore, had no significant effect on the animal's in situ diet.

Our estimate of the total carbon gained by Dendropoma maximum per net cycle at the shallow site is an order of magnitude lower than that of Kappner et al. (2000), obtained at a nearby site. This discrepancy can be partially attributed to the differences in methodology. Kappner et al. (2000) measured total carbon content of mucus nets collected on the reef flat and then subtracted a fixed value of the carbon content of 'empty' nets (obtained from animals in a container filled with filtered seawater). Our results show that the weight of the mucus net is dependent on current speed and can change almost an order of magnitude in size when flow speed changes from 3.5 to $5.5 \mathrm{~cm} \mathrm{~s}^{-1}$. Thus, the weight of empty nets obtained in a container with little or no water motion could have substantially underestimated the carbon content of the net excreted by the animal in situ under substantial water motion, thereby overestimating the carbon content of the food trapped by the net. Another difference between the method we use and that of Kappner et al. (2000), is that we always used fresh nets that were deployed for exactly $20 \mathrm{~min}$ in the water. Since the nets are often extended for longer periods, the possible use of longer-exposed nets by Kappner et al. could have resulted in more trapped food per net. Finally, some of the difference between our results and those of Kappner et al. could also be related to the fact that the nets we sampled were collected $1.5 \mathrm{~m}$ below the reef flat, where the mucus nets were typically smaller (by $26 \%$ ) than the nets on the reef flat 
(Table 2). However, the suggestion by Kappner et al. (2000) that the daily ingestion of D. maximum amounts to $41 \%$ of its weight, should be taken with caution. This ration is greater than that of flying endothermic animals (e.g. 24 to $10 \%$ for piscivorous birds, Nilsson \& Nilsson 1976). The order-of-magnitude lower values of food ingested per net reported in the present study, suggest a much lower ration and appear to be more realistic for this type of ectothermic, sessile mollusc.

Our current measurements were made as close to the bottom as was possible $(50 \mathrm{~cm})$. The current speed at this depth is expected to be stronger than at $<1 \mathrm{~cm}$ above the bottom. Genin et al. (2002) measured the flow at $8 \mathrm{~cm}$ above the bottom at a depth of $8.5 \mathrm{~m}$ and found that the current speed was $<3 \mathrm{~cm} \mathrm{~s}^{-1} 67 \%$ of the time. Hence, the absence of oscillatory motions greatly reduced the spreading of the mucus net, as indicated by our flume experiments at $3.5 \mathrm{~cm} \mathrm{~s}^{-1}$.

The mucus net of Dendropoma maximum is welladapted for trapping near-bed particles in the wave zone. The net is flexible and strongly adheres to the substrate, allowing a collecting area remarkably larger than the animal's aperture. The flexibility of the mucus net may reduce the impact of the waves (Koehl et al. 1991) and allows its large size. That the animal can modulate the size of the net as a function of the flow, allows further optimization of its usage.

Acknowledgements. We thank I. Kappner, K. Richter and M. Kiflawi for providing helpful comments on an earlier draft. Special thanks go to the staff of the H. Steinitz Marine Biology Laboratory for logistical support. I. Aylon, T. Eviatar, S. Rickel and $\mathrm{K}$. Welland helped in dives and sampling. M. Ohavia gave technical assistance with the flume. A. Hudson suggested the use of $\mathrm{NaOCl}$ in analyzing the mucus net content. The Israeli Nature and National Parks Protection Authority granted permits to collect and transplant the Dendropoma maximum used in this study. This research was supported by the Israel Science Foundation, funded by the Israel Academy of Science and Humanities.

\section{LITERATURE CITED}

Denny MW (1988) Biology and the mechanics of the waveswept environment. Princeton University Press, Princeton, NJ

Denny MW, Shibata MF (1989) Consequence of surf-zone turbulence for settlement and external fertilization. Am Nat 134:859-889

Fabricius K, Yahel G, Genin A (1998) In-situ depletion of phytoplankton by an azooxanthellate soft coral. Limnol Oceanogr 43:354-356

Genin A, Paldor N (1999) Changes in the circulation and current spectrum near the tip of the narrow, seasonally mixed Gulf of Eilat. Israel J Earth Sci 47:87-92

Genin A, Gal G, Haury L (1995a) Copepod carcasses in the ocean. II. Near coral reefs. Mar Ecol Prog Ser 123:65 -71

Genin A, Lazar B, Brenner S (1995b) Atmospheric cooling, unusual vertical mixing and coral mortality following the eruption of Mt. Pinatubo. Nature 377:507-510
Genin A, Yahel G, Reidenbach MA, Monismith SG, Koseff JR (2002) Intense benthic grazing on phytoplankton in coral reefs revealed using the control volume approach. Oceanography 15:90-96

Hughes RN, Lewis AH (1974) On the spatial distribution, feeding and reproduction of the vermetid gastropod Dendropoma maximum. J Zool Lond 172:531-547

Kappner I, Al-Moghrabi SM, Richter C (2000) Mucus-net feeding by the vermetid gastropod Dendropoma maxima in coral reefs. Mar Ecol Prog Ser 204:309-313

Keen AM (1961) A proposed reclassification of the gastropod family Vermetidea. Bull Br Mus (Nat Hist) Zool 7:183-213

Koehl MAR, Hunter T, Jed J (1991) How do body flexibility and length affect hydrodynamic forces on sessile organisms in waves versus in currents? Am Zool 31:60A

LaBarbera M (1978) Particle capture by a Pacific brittle star: experimental test of the aerosol suspension feeding model. Science 201:1147-1149

LaBarbera M (1984) Feeding currents and particle capture mechanism in suspension feeding animals. Am Zool 24: 71-84

Loya Y (1976) Recolonization of Red Sea corals affected by natural catastrophes and man-made perturbations. Ecology 57:278-289

Lugo-Fernandes A, Roberts HH, Suhayda JN (1998) Wave transformation across a Caribbean fringing-barrier coral reef. Cont Shelf Res 18:1099-1124

Miller DC, Sternberg RW (1988) Field measurements of the fluid and sediment-dynamics environment of a benthic deposit feeder. J Mar Res 46:771-796

Miller DC, Bock MJ, Turner EJ (1992) Deposit and suspension feeding in oscillatory flows and sediment fluxes. J Mar Res 50:489-520

Morton JE (1950) Feeding mechanisms in the Vermetidae (order Mesogastropoda). Nature 4206:923-924

Muschenheim DK (1987) The dynamics of near-bed seston flux and suspension-feeding benthos. J Mar Res 45: 473-496

Navarro JM, Widdows J (1997) Feeding physiology of Cerastoderma edule in response to a wide range of seston concentrations. Mar Ecol Prog Ser 152:175-186

Nilsson SG, Nilsson IN (1976) Numbers, food consumption, and fish predation by birds in Lake Mockeln, Southern Sweden. Ornis Scand 7:61-70

Omori M, Ikeda T (1984) Methods in marine zooplankton ecology. John Wiley \& Sons, New York

Reiss Z, Hottinger L (1984) The Gulf of Aqaba (Elat) - ecological micropaleontology. Springler-Verlag, Berlin

Riisgard HU (1989) Properties and energy cost of the muscular piston pump in the suspension feeding polychaete Chaetopterus variopedatus. Mar Ecol Prog Ser 56: 157-168

Riisgard HU (1991) Suspension feeding in the polychaete Nereis diversicolor. Mar Ecol Prog Ser 70:29-37

Riisgard HU, Manriquez P (1997) Filter feeding in fifteen ectoprocts (Bryozoa): particle capture and water pumping. Mar Ecol Prog Ser 154:223-239

Riisgard HU, Thomassen S, Jakobsen H, Weeks JM, Larsen PS (1993) Suspension feeding in marine sponges Halichondria panicea and Halichondria urceolus: effects of temperature on filtration rate and energy cost of pumping. Mar Ecol Prog Ser 96:177-188

Rodriguez J, Mullin MM (1986) Relation between biomass and body weight of plankton in a steady state oceanic ecosystem. Limmol Oceanogr 31:361-370

Rubenstein DI, Koehl MAR (1977) The mechanism of filter feeding: some theoretical considerations. Am Nat 111:981-994 
Smalley TL (1984) Possible effect of intraspecific competition on the population structure of a solitary vermetid mollusc. PSZN I: Mar Ecol 14:139-144

StatSoft (1995). STATISTICA for Windows [computer program manual]. Statsoft, Tulsa, OK

Strickland JDH, Parsons TR (1972) A practical handbook of seawater analysis. Bulletin 167 Fisheries Research Board of Canada, Ottawa

Taghon GL, Nowell ARM, Jumars PA (1980) Induction of suspension feeding in spionid polychaetes by high particulate fluxes. Science 210:562-564

Trager GC, Genin A (1993) Flow velocity induces: a switch from active to passive suspension feeding in the porcelain

Editorial responsibility: Otto Kinne (Editor-in-Chief), Oldendorf/Luhe, Germany crab Petrolisthes leptocheles (Heller). Biol Bull (Woods Hole) 185:20-27

Trager GC, Hwang JS, Stricker JR (1990) Barnacle suspension-feeding in variable flow. Mar Biol 105: 117-127

Underwood AJ (1981) Techniques of analysis of variance in experimental marine biology and ecology. Oceanogr Mar Biol Annu Rev 19:513-605

Wildish D, Kristmanson D (1997) Benthic suspension feeders and flow. Cambridge University Press, Cambridge

Yahel G, Post A, Fabricius K, Marie D, Vaulot D (1998) Phytoplankton distribution and grazing near coral reefs. Limnol Oceanogr 43:551-555

Submitted: January 1, 2003; Accepted: February 2, 2005

Proofs received from author(s): May 10, 2005 